\title{
Range Extension of the Collared Black-headed Snake, Sibynophis collaris (Gray 1853): A New Record from Southeastern Bangladesh
}

\author{
Sanjoy Biswas Kajol ${ }^{1}$, Md. Fazle Rabbe², Mahfuzur Rahman ${ }^{3}$, Adnan Azad Asif ${ }^{4}, \mathrm{KH}$ Newaz, Md. Sarafat', and Ashikur \\ Rahman Shome ${ }^{2}$ \\ ${ }^{1}$ Banskhali Degree College, Chittagong, Chattogram, Bangladesh \\ ${ }^{2}$ Department of Zoology, University of Dhaka, Dhaka, Bangladesh \\ ${ }^{3}$ Department of Philosopy, Jahangirnagar University, Dhaka, Bangladesh \\ ${ }^{4}$ Akij Wildlife Farm Ltd., Dhaka, Bangladesh \\ ${ }_{5}^{5}$ Dhamrai Government University College, Dhamrai, Dhaka, Bangladesh (shomear61@gmail.com)
}

$\mathrm{T}^{\mathrm{h}}$ he Collared Black-headed Snake (Sibynophis collaris) ranges from India, Nepal, Bhutan, Bangladesh, Myanmar, Thailand, Laos, Vietnam, Cambodia (?), West Malaysia, and into China and Taiwan (Bain et al. 2007; Bain 2010; Uetz et al. 2020). In Bangladesh, the species has been recorded in Lawachara National Park and the Rajkandi Reserve Forest near Moulvibazar in the northeastern part of the country (Rahman et al. 2013a; 2013b).

On 12 May 2020, we found an adult (total length $\sim 90$ cm) Collared Black-headed Snake (Sibynophis collaris) (Fig. 1) in Jamchiori Village, Nikhongchari, Bandarban, Bangladesh $\left(21^{\circ} 25^{\prime} 37.1^{\prime \prime N}, 92^{\circ} 10^{\prime} 50.8^{\prime \prime E}\right)$ (Fig. 2). We identified the snake based on descriptions in Hasan et al. (2014) and Khan (2018). The habitat in the area is mixed evergreen forest. Although this new record is approximately $470 \mathrm{~km}$ south of previously known locations in Bangladesh, populations of this species likely exist in forested habitats in intervening areas.

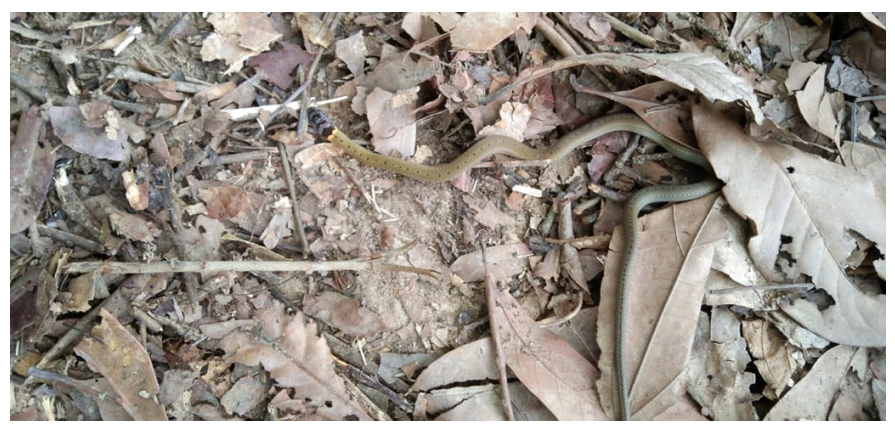

Fig. 1. A Collared Black-headed Snake (Sibynophis collaris) from Jamchiori Village, Nikhongchari, Bandarban, Bangladesh. Photograph by Sanjoy Biswas Kajol.

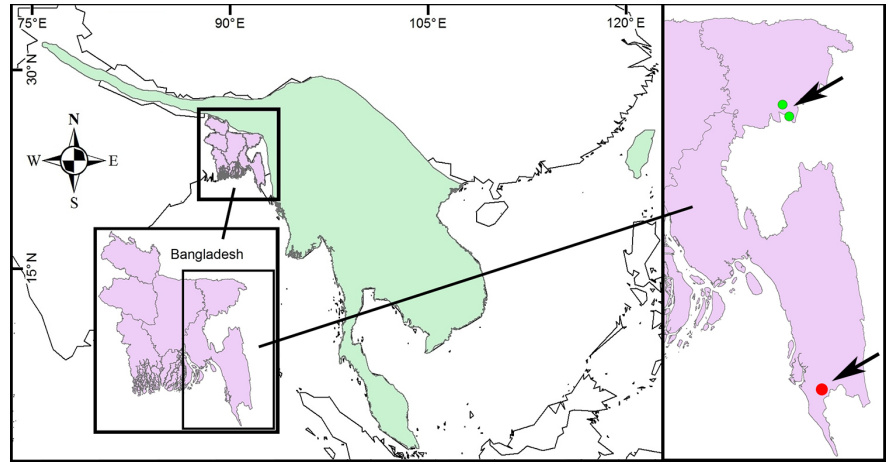

Fig. 2. Map showing the global range (pale green) and Bangladeshi records of the Collared Black-headed Snake (Sibynophis collaris). Previous records in Lawachara National Park and the Rajkandi Reserve Forest near Moulvibazar are indicated by green dots; the new record is indicated by the red dot.

\section{Literature Cited}

Bain, R.H. 2010. Sibynophis collaris. The IUCN Red List of Threatened Species 2010: e.T177571A7459286.

Bain, R.H., T.Q. Nguyen, and K.V. Doan. 2007. New herpetofaunal records from Vietnam. Herpetological Review 38: 107-117.

Hasan, M.K., M.M.H. Khan, and M.M. Feeroz. 2014. Amphibians and Reptiles of Bangladesh - A Field Guide. Arannayk Foundation, Dhaka, Bangladesh.

Khan, M.M.H. 2018. A Photographic Guide to Wildlife of Bangladesh. Arannayk Foundation, Dhaka, Bangladesh.

Rahman, S.C., S.M.A. Rashid, K. Das, and L. Luiselli. 2013a. Composition and structure of a snake assemblage in an altered tropical forest-plantation mosaic in Bangladesh. Amphibia-Reptilia 34: 41-50.

Rahman, S.C., S.M.A. Rashid, K. Das, C. Jenkins, and L. Luiselli. 2013b. Monsoon does matter: Annual activity patterns in a snake assemblage from Bangladesh. The Herpetological Journal 23: 203-208.

Uetz, P., P. Freed, and J. Hošek (eds.). 2020. The Reptile Database. <http://www. reptile-database.org>. 